\title{
Changes of Nitrogen and Organic Compound During Co-Composting of Disposable Diaper and Vegetable Wastes on Aerobic Process
}

\author{
Ellina S. Pandebesie ${ }^{1 *}$, Idaa Warmadewanthi", \\ Susi Agustina Wilujeng ${ }^{1}$, Minar Saraswati Simamora' \\ 1 Departement of Environmental Engineering, Institut Teknologi Sepuluh Nopember, Jl. Teknik Kimia, Keputih, \\ Kec. Sukolilo, Kota SBY, Jawa Timur 60111, Indonesia \\ * Corresponding author's e-mail: ellina@its.sc.id
}

\begin{abstract}
The use of disposable diapers is increasing every year, increasing generated diaper wastes every year. In Surabaya, diaper wastes have become an important issue when they are not treated properly. These diaper wastes will end up in water bodies and cause pollution. One of the technologies that can be used to treat diaper wastes is composting. Disposable diaper wastes consist of high lignocellulose and $\mathrm{C}$ content. It is necessary to mix diaper wastes and other wastes with high $\mathrm{N}$ content as a co-substrate, so that the optimum $\mathrm{C} / \mathrm{N}$ ratio of composting can be achieved. In this research, vegetables wastes were used. The Objective of the research was to determine the effect of vegetable wastes adding as a co-substrate in composting of disposable diapers and volatile solid (VS), C-organic, and Total Nitrogen (TN) content changed during the composting process. The research was carried out with three variables mixtures of diaper wastes and vegetable wastes. Two control consist of $100 \%$ diaper wastes and $100 \%$ vegetables wastes. The Total weight of raw materials was $10 \mathrm{~kg}$ for each reactor. The composting process is carried out aerobically with a composting time of 60 days. The results showed that vegetable wastes have the potential to be used as a co-substrate for diaper wastes. The content of C-organic, VS and total nitrogen decreased. All of the parameters include $\mathrm{C} / \mathrm{N}$ ratio meet the Indonesian Standard of compost.
\end{abstract}

Keywords: aerobic, $\mathrm{C} / \mathrm{N}$ ratio, composting, diaper wastes, vegetables waste, volatile solid.

\section{INTRODUCTION}

The use of disposable diapers is not only for the needs of babies but also the elderly and sick people, therefore, the number of disposable diaper wastes continues to increase every year. These diapers wastes are the fourth largest composition in Surabaya. In general, these wastes are disposed of in landfills without prior processing. Most household wastes can be used as raw material for compost. Household-scale composting will reduce the volume of waste that must be transported to the landfill and the compost can be used as organic fertilizer for household purposes. Some of it is thrown into water bodies, thus polluting the river.

Diapers consist of 4 layers (Baldwin, et al., 2001), the first layer contains polypropylene and lotion. The second layer consists of cellulose and polyester. The third layer consists of a superabsorbent polymer gel which is usually mixed with cellulose. Urine will be locked and stored in a superabsorbent polymer. The fourth layer or the outer layer of the diaper is made of polypropylene fabric whose function is to prevent liquid from leaking from the diaper. The content of cellulose polymer compounds (Colon et al., 2011) cause a high $\mathrm{C} / \mathrm{N}$ ratio. This is what makes disposable diapers difficult to decompose by microorganisms, because the optimum $\mathrm{C} / \mathrm{N}$ ratio for composting is 20-40 (Tchobanoglous et al., 1993; Chen et al., 2011). Disposable diapers have the potential to be used as raw material for compost, if other organic materials with high $\mathrm{N}$ content are added. One of the wastes that can be used as co-substrate 
is vegetable waste because it contains a low $\mathrm{C} / \mathrm{N}$ ratio (Kumar et al., 2010; Musa et al., 2020), so it is suitable if mixed with waste containing a high $\mathrm{C} / \mathrm{N}$ ratio. Apart from households, large amounts of vegetable wastes can be obtained from agricultural activities, supermarkets, and markets (Pavi et al., 2017). Vegetable waste has a high level of moisture and biodegradability (Yuanyuan et al., 2016) and increase the $\mathrm{N}$ content in compost products (Kim et al., 2018). The combination of disposable diapers and vegetable waste is suitable for use in household composting. This combination still requires the addition of chemical fertilizers so that the optimum $\mathrm{C} / \mathrm{N}$ ratio can be met.

The composting process can be done both anaerobically and aerobically. Because the application of this research will be applied on a household scale, the aerobic process was chosen. The aerobic process takes place more quickly (Ponsa et al., 2008) and does not cause odor. The results of the compost are also drier, so they do not require the process of maturation and drying. This study aims to compare the effectiveness of adding vegetable wastes as a co-substrate in composting disposable diapers with an aerobic process and changes in Volatile Solid, C-organic and Nitrogen content during the composting process.

\section{MATERIALS AND METHOD}

\section{Materials}

The diaper wastes used in this study was solid wastes taken from the baby care home. Diaper wastes are cleaned from baby feces and then dried naturally. Vegetable wastes are obtained from traditional market around the ITS campus, Surabaya and urea is purchased from commercial shops.

\section{Experimental design}

Diaper wastes and vegetable wastes were chopped manually to be size of less than $5 \mathrm{~cm}$. The smaller the particle size, the faster waste decomposition takes place (Bolado-Rodriguez, et al., 2016). If the particle size is too large, the surface area will be smaller so that the microbes are less able to decompose the material (Verma and Marschner, 2013). According to Duong et al. (2012) small particle size can produce high levels of $\mathrm{N}$ and $\mathrm{P}$. Then the diaper wastes are mixed with vegetable wastes with the addition of urea as much as $10 \mathrm{gr}$ per each reactor. Total mixed weight of each reactor was $10 \mathrm{~kg}$. The compost material was put into a perforated reactor with a volume capacity of 50 liters. The reactor is covered with gauze, so that air can enter freely. Stirring is done every 3 days, so that no part of the waste is deprived of oxygen. The research variables were carried out by mixing the diaper wastes and vegetable wastes, which the ratio of diaper wastes and vegetable wastes as follows: $\mathrm{R}_{1}=10: 1$ (diaper wastes only); $\mathrm{R}_{2}=7: 3 ; \mathrm{R}_{3}=5: 5$; $R_{4}=3: 7$ and $R_{5} 0: 10$ (vegetable wastes only). The research was conducted for 60 days. The parameters analysis can be seen in Table 1 . The quality of the compost produced was compared with the Indonesian Standard for Compost (SNI).

\section{RESULTS AND DISCUSSIONS}

\section{Temperature and moisture content relationship}

Figure 1 shows the temperature changes that occurred during composting processes. At the beginning of the composting the temperature of each reactor was $29.2^{\circ} \mathrm{C}$. The temperature increased sharply until day $3^{\text {th }}$ and then decreased sharply until day $6^{\text {th }}$. After that the temperature fluctuated, but decreased slowly until it reached a temperature of around $30^{\circ} \mathrm{C}$ on day $30^{\text {th }}$. Then the temperature stabilized until the end of composting, reaching a temperature of about $29^{\circ} \mathrm{C}$ on day $60^{\text {th }}$.

The metabolism of organic matter by microorganisms released heat which caused the temperature inside the reactor increased. The temperature in this research was not more than $47.2^{\circ} \mathrm{C}$, so it can be concluded that only mesophilic microorganisms were able to reproduce and metabolize the available organic matter. Types of microorganisms that can be more effective in decomposing waste in a mesophilic manner are proteobacteria and fungi (Tang et al., 2007). The initial water content in reactor $\mathrm{R}_{1}, \mathrm{R}_{2}, \mathrm{R}_{3}, \mathrm{R}_{4}$ and $\mathrm{R}_{5}$ were

Table 1. Parameters analysis method

\begin{tabular}{|l|c|}
\hline \multicolumn{1}{|c|}{ Parameter } & Analysis method \\
\hline C-Organic & Black and Welkey \\
\hline $\mathrm{N}$ total & Spectrofotometer \\
\hline $\begin{array}{l}\text { Water content, total solid } \\
\text { and volatile solid }\end{array}$ & Gravimetry \\
\hline $\mathrm{pH}$ & $\mathrm{pH}$ indicator \\
\hline Temperature & Thermometer \\
\hline
\end{tabular}



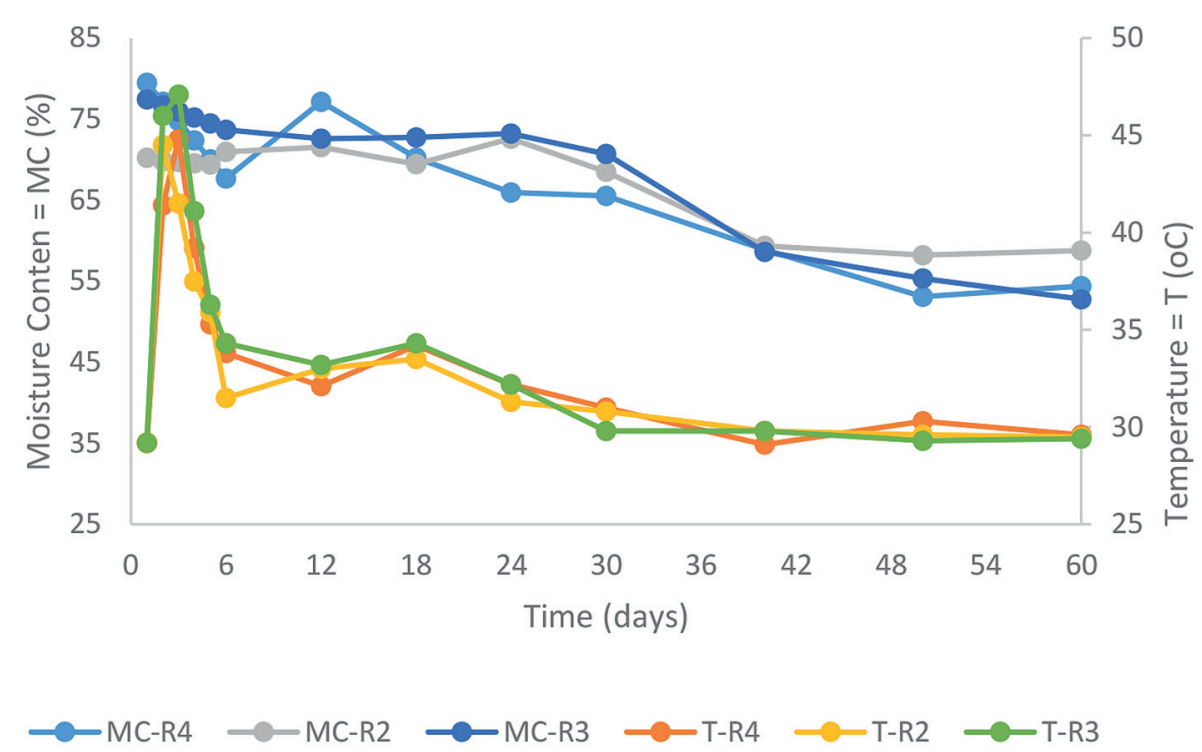

Figure 1. The relationship of temperature and water content decrease

$78.83 \% ; 70.26 \% ; 77.45 \% ; 79.49 \%$ and $66.67 \%$ respectively, where based on Ahn et al., (2008) research the optimum composting water content ranges from $60-80 \%$. For composting organic waste, relatively high moisture contents are better at achieving higher temperatures and retaining them for longer times (Makan et al., 2013 ). If the temperature increased,water content will drop, it will cause the water shortage, so inhibit the microbial metabolism (Rastogi et al., 2020). After the sixth day, the water content varies from 50 to $60 \%$. Based on Li et al., (2021) research, moisture content around $53 \%$ is effectively prevented leaching and nutrient loss, which is in accordance with the results in this study (Figure 3). At the end of composting, the water content of $\mathrm{R}_{1}, \mathrm{R}_{2}, \mathrm{R}_{3}$, $\mathrm{R}_{4}$ and $\mathrm{R}_{5}$ was $57.21 \%$; $58.78 \%$; $52.8 \%$; $54.41 \%$; and $53.65 \%$. This water content is slightly higher than the compost standard (SNI) where the water content is $50 \%$. After the composting process, the compost is continued with the next stage, namely the cooling and maturation process where drying also occurs which reduces the water content, so that the maximum moisture content of the compost can be achieved.

$\mathrm{pH}$ at reactor $\mathrm{R}_{1}, \mathrm{R}_{2}, \mathrm{R}_{3}, \mathrm{R}_{4}$ and $\mathrm{R}_{5}$ was 7.56 ; $8.18 ; 7.91 ; 7.95$ and 7.1 . The $\mathrm{pH}$ value during the composting process fluctuates. Changes in $\mathrm{pH}$ indicate the activity of microorganisms in degrading organic matter. Metabolic activity of various heterogeneous group of microorganisms results in increased temperature as these microbes utilizes the $\mathrm{N}$ and $\mathrm{C}$ of the organic matter for their body assimilation. Bacteria utilize soluble compounds such as sugars, amino acids and lipids found in the raw material of compost, which produces organic acids and hence, the $\mathrm{pH}$ can drop (Sanchez et al., 2017; Meena et al., 2020). The optimum $\mathrm{pH}$ for the composting process ranges from $6.5-7$ (Zhang et al., 2016). If the $\mathrm{pH}$ is too low, it will inhibit the growth of microorganisms, slow the temperature rise and prolong the composting time (Jiang et al., 2014).

\section{Changes in total solid and volatile solid content during composting}

The increase of Total Solid in all reactors at the end of composting was around of $20.51 \%$ to $33.33 \%$, as can be seen in Table 2. During the composting process, the total solid content increased because some of the volatile solids had been metabolized by microorganisms. This increase in total solid pocket indicates the activity of microorganisms. The decreased of VS in each reactor can be seen in Table 3. The initial contents of each $\mathrm{R}_{1}, \mathrm{R}_{2}, \mathrm{R}_{3}, \mathrm{R}_{4}$ and $\mathrm{R}_{5}$ were $82.9 ; 79.17$; $77.32 ; 68.87$ and 82.07 . The decrease in VS content varied by $5 \%$ in diaper waste $\left(\mathrm{R}_{1}\right)$ to $64 \%$ in vegetable waste $\left(\mathrm{R}_{5}\right)$. The addition of vegetable wastes can increase the rate of decrease in VS levels $\left(\mathrm{R}_{2}, \mathrm{R}_{3}\right.$ and $\left.\mathrm{R}_{4}\right)$ when compared to without the addition of vegetable waste $\left(R_{1}\right)$. The decrease of VS in the $\mathrm{R}_{3}$ mixed reactor was achieved by $12.73 \%$ for 60 days. Based on Cabanas-Vargas et al. (2005) research, VS was degraded by $28 \%$ 
Table 2. Total solid content

\begin{tabular}{|c|c|c|c|c|c|c|c|c|c|c|c|}
\hline Days & 0 & 6 & 12 & 18 & 24 & 30 & 40 & 50 & 60 & Increased \\
\hline \multicolumn{9}{|c|}{$(\%)$} \\
\hline $\mathrm{R}_{1}$ & 21.17 & 25.49 & 26.36 & 27.24 & 24.46 & 33.04 & 41.41 & 42.23 & 42.79 & 102.13 \\
\hline $\mathrm{R}_{2}$ & 29.74 & 29.04 & 28.46 & 30.56 & 27.39 & 31.46 & 40.63 & 41.77 & 41.22 & 38.60 \\
\hline $\mathrm{R}_{3}$ & 22.55 & 26.29 & 27.40 & 27.24 & 26.78 & 29.30 & 41.38 & 44.66 & 47.20 & 109.31 \\
\hline $\mathrm{R}_{4}$ & 20.51 & 32.33 & 22.84 & 29.76 & 34.07 & 34.48 & 41.11 & 46.90 & 45.59 & 122.28 \\
\hline $\mathrm{R}_{5}$ & 33.33 & 55.47 & 47.59 & 49.54 & 52.34 & 56.18 & 48.51 & 45.16 & 46.35 & 39.06 \\
\hline
\end{tabular}

Table 3. Volatile solid content

\begin{tabular}{|c|c|c|c|c|c|c|c|c|c|c|c|}
\hline Days & 0 & 6 & 12 & 18 & 24 & 30 & 40 & 50 & 60 & Decreased \\
\hline \multicolumn{9}{|c|}{$(\%)$} \\
\hline $\mathrm{R}_{1}$ & 82.90 & 81.51 & 74.56 & 82.65 & 75.36 & 77.20 & 75.95 & 77.17 & 78.55 & 5.25 \\
\hline $\mathrm{R}_{2}$ & 79.17 & 76.93 & 72.91 & 81.33 & 69.66 & 71.56 & 78.40 & 71.06 & 74.28 & 6.18 \\
\hline $\mathrm{R}_{3}$ & 77.32 & 77.28 & 75.55 & 80.63 & 66.72 & 63.44 & 67.48 & 73.53 & 67.48 & 12.73 \\
\hline $\mathrm{R}_{4}$ & 68.87 & 73.24 & 79.41 & 68.25 & 56.07 & 55.37 & 60.34 & 59.20 & 60.34 & 12.39 \\
\hline $\mathrm{R}_{5}$ & 82.07 & 62.34 & 53.31 & 53.08 & 55.93 & 49.94 & 40.22 & 49.53 & 29.04 & 64.62 \\
\hline
\end{tabular}

during the 8 weeks of the composting process, while in the study of Lemus and Lau (2002) VS degradation reaches $20 \%$ during 10 days. Diaper degradation is slow because all diaper materials are used as raw materials contains plastic. To get better results, plastic should be separated from other materials and not composted. The decrease in VS content until day $24^{\text {th }}$ indicated that microorganisms degrade organic matter that is easily decomposed (Bernal et al., 2009). The composting process is maintained under aerobic conditions, by turning the pile of garbage every three days and the reactor is perforated for air in and out. The composting process will produce $\mathrm{CO}_{2}$, $\mathrm{CO}, \mathrm{CH}_{4}, \mathrm{H}_{2}, \mathrm{H}_{2} \mathrm{O}, \mathrm{NH}_{3}$ and $\mathrm{H}_{2} \mathrm{~S}$ which is released into the ambient air (Esparza et al., 2020).

\section{Changes in C-organic content during composting}

The decrease in C-organic content occurred in all reactors as can be seen in Figure 2. At the beginning of composting, the C-organic content of $\mathrm{R}_{5}$ was the lowest, according to the compost raw material which only contained market wastes. After mixing, the initial $\mathrm{C}$-organic content in each reactor ranged from $50-60 \%$. The decrease in organic $C$ content in $R_{1}, R_{2}, R_{3}$, and $R_{5}$ from the first to the sixth day occurred rapidly, where the decrease in $\mathrm{R}_{4}$ was the fastest. While at $\mathrm{R}_{2}$ measurement of $\mathrm{C}$-organic content there was an increase.
The increase in C-organic content can be measured, if at the time of sampling the test material taken contains plastic. In this study, diaper wastes are not separated from plastic raw materials. It facilitates the preparation of compost raw materials, if composting will be applied on a household scale. After linearization of the graph of the decrease in $\mathrm{C}$-organic content, the correlation number of $R_{2}$ at $R_{1}, R_{2}, R_{3}$ and $R_{4}$ ranged from 0.68 to 0.78 except for $R_{5}$ the $R_{2}$ value was 0.39 . From the $\mathrm{R}_{2}$ value, it can be concluded that the composting process follows the reaction rate of first order. $\mathrm{R}_{5}$ should also follow the reaction rate of the first order, but because the raw material are vegetable wastes which contains high lignocellulosic content, a longer composting time is required. Or to shorten the composting time, pretreatment is needed to break down the lignocellulose, before composting is carried out. The results of linearization obtained that the reaction rates of $\mathrm{R}_{1}, \mathrm{R}_{2}$, $\mathrm{R}_{3}, \mathrm{R}_{4}$ and $\mathrm{R}_{5}$ were $-0.70 ;-0.68 ;-0.60 ;-0.72$ and -0.22 respectively.

If the values of $R_{1}$ and $R_{4}$ are compared, where the initial $\mathrm{C}$ content is almost the same, then the addition of vegetable wastes only increases the rate of composting by 0.02 . Although the $\mathrm{N}$ content in diaper wastes is very limited, microorganisms from feces and urine can still metabolize diaper wastes. The nitrogen content in diaper wastes comes from the baby's urine. Urine is perhaps the most promising product as it contains relatively 


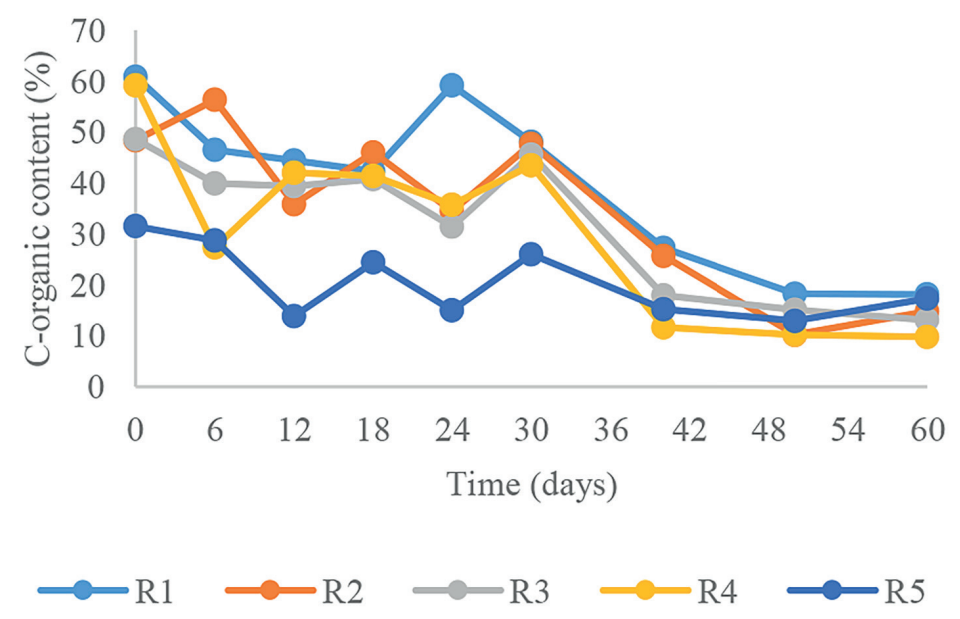

Figure 2. Decrease of C-organic content

high concentrations of $\mathrm{N}$ (up to $9 \mathrm{~g} \mathrm{~N} / \mathrm{l}$ ), $\mathrm{P}$ (around $0.7 \mathrm{~g} \mathrm{P} / \mathrm{l}$ ) and other nutrients such as $\mathrm{K}$, sulphur (S), and micronutrient (Winker et al., 2009). The Food/Microorganism (F/M) ratio is very important in the success of the biological waste treatment process (Guo et al., 2017). The results of this study indicate that the addition of vegetable wastes can increase the rate of composting diaper wastes at the ratio of the composition of diaper wastes and vegetable wastes by $3: 7$.

\section{Total nitrogen content during composting processes}

Total Nitrogen (TN) is the sum of nitratenitrogen $\left(\mathrm{NO}_{3}-\mathrm{N}\right)$, nitrite-nitrogen $\left(\mathrm{NO}_{2}-\mathrm{N}\right)$, ammonia-nitrogen $\left(\mathrm{NH}_{3}-\mathrm{N}\right)$ and organically bonded nitrogen. Nitrogen is the main element in the composting process because nitrogen contributes to the growth of microorganisms (Campitelli and Ceppi, 2008). During the composting process, a nitrogen cycle occurs which includes ammonification, nitrification, assimilation, immobilization and denitrification. Initial TN content of $\mathrm{R}_{1}, \mathrm{R}_{2}, \mathrm{R}_{3}, \mathrm{R}_{4}$ and $\mathrm{R}_{5}$ was $0.3 ; 0,31 ; 0.42 ; 0.38$, and 0.5 respectively. The total nitrogen content in reactors $\mathrm{R}_{2}, \mathrm{R}_{3}$ and $\mathrm{R}_{4}$ increased until the day $30^{\text {th }}$ by $75.83 \%, 73.15 \%$ and $70.22 \%$, whereas control reactors $\mathrm{R}_{1}$ and $\mathrm{R}_{5}$ increased by $64.96 \%$ and $83.80 \%$ as can seen in Figure 3. Control reactors $\mathrm{R}_{1}$ and $\mathrm{R}_{5}$, total nitrogen content decreased by $45.73 \%$ and $62.68 \%$, while the reactors $\mathrm{R}_{2}, \mathrm{R}_{3}$ and $\mathrm{R}_{4}$ were $69.62 \%, 56.74 \%$ and $21.01 \%$. The greatest decline occured on reactor $\mathrm{R}_{2}$. At the end of composting, it can be seen that the compost in all reactors met the minimum standard for TN content, which was $0.4 \%$. Increasing the TN content in each reactor concluded that the addition of vegetable waste can increase the $\mathrm{N}$ content in the diaper waste composting process.

\section{$\mathrm{C} / \mathrm{N}$ ratio}

The $\mathrm{C} / \mathrm{N}$ ratio is one of the factors that affect the composting process and quality (Zhu, 2007; Zhang and Sun, 2016). In this study, the value of the $\mathrm{C} / \mathrm{N}$ ratio was obtained from the comparison of the value of C-Organic with Total Nitrogen. In this study, the initial $\mathrm{C} / \mathrm{N}$ ratio was very high, even though urea was added as the source of $\mathrm{N}$. At the beginning of composting the $\mathrm{C} / \mathrm{N}$ ratio was greater than 40 as can be seen in Fig.4. But, composting process continued even though it is slow, because of the sufficient number of microorganisms. According to El Haggar (2005) decomposition of the organic waste material will slow down if $\mathrm{C} / \mathrm{N}$ ratios are as low as $10: 1$ or as high as 50:1. The high $\mathrm{C}$ content causes the microorganisms to lack $\mathrm{N}$ which inhibits the proliferation of microorganisms. If $\mathrm{C} / \mathrm{N}$ ratio decreased below 15, the compost had satisfied an acceptable standard of maturation (Bernal et al., 2009), while according to SNI below 20. The $\mathrm{C} / \mathrm{N}$ ratio of $\mathrm{R}_{4}$ was reached 11 in the 40 days and $R_{5}$ was reached 10.3 in the 6 days.

\section{CONCLUSSIONS}

Vegetable wastes has the potential as a cosubstrate to increase the composting rate of diaper wastes. The composting process occured 


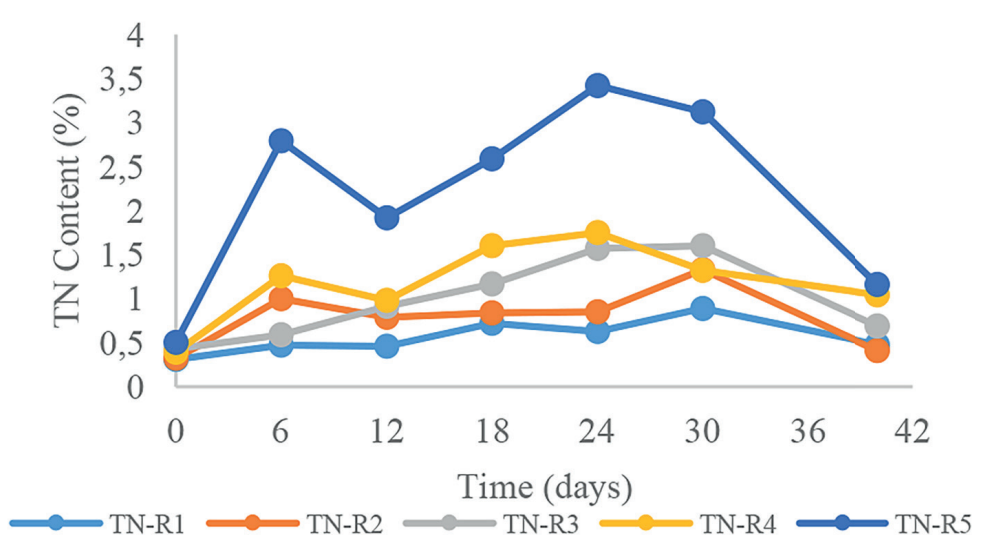

Figure 3. TN content during composting processes

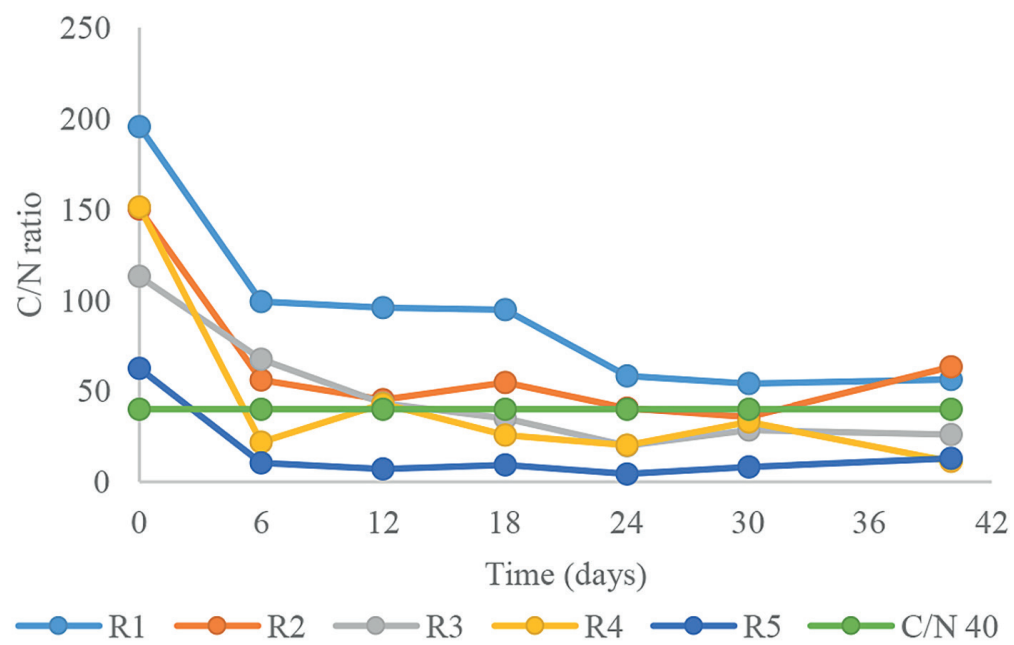

Figure 4. C/N Ratio during composting processes

throughout all reactors by utilizing microorganisms found in diaper wastes and vegetable wastes. The quality of the compost in the $\mathrm{R}_{4}$ met the Indonesian national standard compost for $\mathrm{pH}$, temperature, $\mathrm{C}, \mathrm{N}, \mathrm{VS}$ and moisture content.

\section{Acknowledgments}

We gratefully acknowledge the financial support by Institut Teknologi Sepuluh Nopember, Indonesia.

\section{REFERENCES}

1. Ahn H.K., Richard T.L., Glanville T.D. 2008. Optimum moisture levels for biodegradation of mortality composting envelope materials. Waste Management, 28, 1411-1416.

2. Baldwin S., Odio M.R., Haines S.L., O'Connor R.J., Englehart J.S., Lane A.T. 2001. Skin Benefits
From Continuous Topical Administration of A Zinc Oxide/Petrolatum Formulation by A Novel Disposable Diaper. Journal of the European Academy of Dermatology and Venereology, 15(1), 5-11.

3. Bernal M.P., Alburquerque J.A., Moral R. 2009. Composting of Animal Manures and Chemical Criteria for Compost Maturity Assessment. A review. Bioresource Technology, 100(22), 5444-5453.

4. Bolado-Rodriguez S., Toquero C., Martin-Juarez J., Travaini R., Garcia-Encina, P.A. 2016. Effect of Thermal, Acid, Alkaline and Alkaline-Peroxide Pretreatments on The Biochemical Methane Potential and Kinetics of The Anaerobic Digestion of Wheat Straw and Sugarcane Bagasse. Journal of Bioresource Technology, 201, 182-190.

5. Cabanas-Vargas D.D., Sanchez-Monedero M.A., Urpilainen S.T., Stentiford E.I. 2005. Assessing The Stability and Maturing of Compost at Large Scale Plants. Artículo de Investigación, Ingeniería, 9-2, 25-30.

6. Campitelli P., Ceppi S. 2008. Chemical, Physical and Biological Compost and Vermicompost Characterization: A Chemometric Study. Journal of Chemometrics 
and Intelligent Laboratory System, 90, 64-71.

7. Chen L., De Haro M.M., Moore A., Falen C. 2011. The Composting Process: Dairy Compost Production and Use in Idaho CIS 1179. University of Idaho.

8. Colon J., Ruggieri L., Gonzales A., Puig I., Sanchez A. 2011. Possibilities of Composting Disposable Diapers With Municipal Solid Wastes. Waste Management and Research, 29(3), 249-259.

9. Duan R., Fedler C.B. 2015. Preliminary Field Study of Soil TKN in A Wastewater Land Application System. Journal of Ecological Engineering, 83, 1-4.

10. Duong T.T.T., Penfold C., Marschner P. 2012. Differential Effects of Composts on Properties of Soils With Different Textures. Biology and Fertility of Soils, 48(6), 699-707.

11. El Haggar S.M. 2005. Food Waste Recycling, Composting. Environmental Solutions. Elsevier Publishing, Chapter, 13, 313-400.

12. Esparza I., Jimenez-Moreno N., Bimbela F., Ancín-Azpilicueta C., Gandía L. M. 2020. Fruit and vegetable waste management: Conventional and emerging approaches. Journal of Environmental Management, 265, 110510, 1-18.

13. Guo N., Zhang. Xie H.J., Tan L.R., Luo J.N., Tao Z.Y., Wang S.G. 2017. Effects of the Food-toMicroorganism (F/M) Ratio on N2O Emissions in Aerobic Granular Sludge Sequencing Batch Airlift Reactors. Water, 9, 477-486.

14. Jiang J.S., Huang Y.M., Liu X.L., Huang H. 2014. The Effects of Apple Pomace, Bentonite and Calcium Superphosphate on Swine Manure Aerobic Composting. Waste Management, 34, 1595-1602.

15. Kim E.Y., Hong Y.K., Lee C.H., Oh T.K., Kim S.C. 2018. Effect of organic compost manufactured with vegetable waste on nutrient supply and phytotoxicity. Applied Biological Chemistry, 61(5), 509-521.

16. Kumar M., Ou Y-L., Lin J-G. 2010. Co-composting of green waste and food waste at low $\mathrm{C} / \mathrm{N}$ ratio. Waste Management, 20, 602-609.

17. Lemus G.R., Lau A.K. 2002. Biodegradation of Lipidic Compounds in Synthetic Food Wastes During Composting. Canadian Biosystem Engineering, 44(6), 33-39.

18. Li M.X., He X.S., Tang J., Li X., Zhao R., Tao Y.Q., Wang C., Qiu Z.P. 2021. Influence of moisture content on chicken manure stabilization during microbial agent-enhanced composting. Chemosphere, 264, 128549.

19. Makan A., Assobhei O., Mountadar M. 2013. Effect of initial moisture content on the in-vessel composting under air pressure of organic fraction of municipal solid waste in Morocco. Iranian Journal of Environmental
Health Sciences \& Engineering, 10(3).

20. Meena A.L., Karwal M., Dutta D., Mishra R.P. 2021. Composting: Phases and Factors Responsible for Efficient and Improved Composting. Agriculture and Food: e-Newsletter, 1, 85-90.

21. Musa A.M., Ishak C.F., Karam D.S., Jaafar N.M. 2020. Effects of Fruit and Vegetable Wastes and Biodegradable Municipal Wastes Co-Mixed Composts on Nitrogen Dynamics in an Oxisol. Agronomy, 10, 1609-1624.

22. Pavi S., Kramer L.E., Gomes L.P., Miranda L.A. 2017. Biogas Production from Co-Digestion of Organic Fraction of Municipal Solid Waste and Fruit and Vegetable Waste. Bioresource Technology, 228, 362-367.

23. Ponsá S., Gea T., Alerm L., Cerezo J., Sánchez A.. 2008. Comparison of aerobic and anaerobic stability indices through a MSW biological treatment process. Waste Management, 28(12), 2735-2742.

24. Rastogi M., Nandal M., Khosla B. 2020. Microbes as vital additives for solid waste composting. Heliyon, 6, e03343.

25. Sanchez O.J., Ospina DA, Montoya S. 2017. Compost Supplementation with Nutrients and Microorganisms in Composting Process. Waste Management, 69, 136-153.

26. Tang J., Atsushi S., Qixing, Arata K. 2007. Effect of Temperature on Reaction Rate and Microbial Community in Composting of Cattle Manure with Rice Straw. Journal of Bioscience and Bioengineering, 104(4), 321-328.

27. Tchobanoglous G., Theisen H., Virgil S. Integrated Solid Waste Management. Second Edition, New York, 1993.

28. Winker M., Vinnerås B., Muskolus A., Arnold U., Clemens J. 2009. Fertiliser products from new sanitation systems: Their potential values and risks. Bioresource Technology, 100, 4090-4096.

29. Yuanyuan W., Wang C., Liu X., Hailing M., Wu J., Zuo J., Wang K. 2016. A New Methode of Two-Phase Anaerobic Digestion for Fruit and Vegetable Waste Treatment. Bioresource Technology, 211(1), 16-23.

30. Zhang J., Chen G., Sun H., Zhou S., Zou G. 2016. Straw Biochar Hastens Organic Matter Degradation and Produces Nutrient-rich Compost. Bioresource Technology, 200, 876-883.

31. Zhang L., Sun X. 2014. Changes in Physical, Chemical, and Microbiological Properties During the Two-Stage Co-composting of Green Waste with Spent Mushroom Compost and Biochar. Bioresource Technology, 171, 274-284.

32. Zhu N.W. 2007. Effect of Low Initial C/N Ratio on Aerobic Composting of Swine Manure with Rice Straw. Bioresource Technology, 98(1), 9-13. 